\title{
ANALISIS KARAKTERISTIK GELOMBANG LAUT MENGGUNAKAN SOFTWARE WINDWAVE-12 (STUDI KASUS : KEPULAUAN MENTAWAI)
}

\author{
Oleh \\ Nadia Friska Marelsa ${ }^{1)}$ dan Yosyea Oktaviandra ${ }^{2)}$
}

\begin{abstract}
CHARACTERISTIC ANALYSIS OF SEA WAVES USING WINDWAVE-12 SOFTWARE (CASE STUDY: MENTAWAI ISLANDS). Territorial water of Mentawai Islands that directly facing to India Ocean has some potency of big waves to happen it has an impact on community activity like fisherman activity, ship crossing and many more. This research is implemented to get the ideas of the characteristic sea waves using Windwaves-12 with data that are used from December 2016 until November 2017. From processing data of Windwaves-12 can be concluded that the highest significant wave value occurs during the western season (December - February) and east season (June - August) with height 0,5 - 2m. In the transition season II (September - November) significant wave height with 0,5 - 2 and the transition season I (March - may) lowest significant wave in 0,5 - 1,25 m until this season still in the safe situation for the people to do their activity.
\end{abstract}

Keywords: Sea waves, Characteristic, Windwaves-12, Mentawai Islands.

\section{PENDAHULUAN}

Kepulauan Mentawai merupakan kumpulan pulau-pulau non vulkanik yang berbentuk bukit dari satu punggung pegunungan di bawah laut dengan luas $6.011,35 \mathrm{~km}^{2}$. Berdasar pada UU RI No. 49 Tahun 1999 tentang Pembentukan Kabupaten Kepulauan Mentawai, kepulauan yang terletak memanjang pada bagian paling barat Pulau Sumatera ini telah menjadi satu kabupaten baru yang otonom atau berdiri sendiri. Kabupaten Kepulauan Mentawai terdiri atas Pulau Siberut (4.097 $\mathrm{km}^{2}$ ), Pulau Sipora (840 $\mathrm{km}^{2}$ ), Pulau Pagai Utara dan Pulau Pagai Selatan $\left(1.870 \mathrm{~km}^{2}\right)$, serta 94 pulau kecil lainnya. Sesuai dengan UU RI No. 27 Tahun 2007 tentang Pengelolaan Wilayah Pesisir dan Pulau-Pulau Kecil, hanya Pulau Siberut yang termasuk dalam pulau besar (Dewi et al., 2017).
Secara klimatologis, wilayah Indonesia sangat dipengaruhi oleh angin barat dan angin timur, pada waktu musim angin barat (angin bertiup dari barat) dari bulan Oktober sampai Maret. Cuaca di Indonesia dipengaruhi oleh monsun barat, angin bertiup dari timur laut dan berbelok menuju arah tenggara setelah melewati khatulistiwa. Sebaliknya pada musim angin timuran, angin bertiup dari tenggara dan berbelok menuju ke timur laut setelah melalui daerah khatulistiwa, dari bulan Mei sampai September.

Posisi Kepulauan Mentawai yang berhadapan langsung dengan Samudra Hindia mengakibatkan potensi kejadian gelombang tinggi cukup sering terjadi sehingga berdampak pada kegiatan masyarakat. Oleh sebab itu, dibutuhkan analisis mengenai aktivitas gelombang yang terjadi di kepulauan Mentawai

\footnotetext{
1) Universitas Maritim Raja Ali Haji

2) Badan Meteorologi, Klimatologi dan Geofisika, Stasiun Meteorologi Maritim Teluk Bayur Padang
} 
sehingga didapatkan gambaran terkait karakter dan pola kejadiannya dalam bentuk peta sebaran tinggi gelombang laut.

Tujuan dari penelitian ini adalah menganalisis karakteristik gelombang yang ada di perairan Kepulauan Mentawai. Hasil dari penelitian ini diharapkan dapat memberikan informasi kepada masyarakat yang melakukan aktivitas di sekitar perairan Kepulauan Mentawai dan bisa dijadikan sebagai referensi untuk penelitian selanjutnya maupun instansi yang membutuhkan data ini.

\section{Gelombang Laut}

Gelombang laut adalah pergerakan naik dan turunnya air laut secara tegak lurus dengan permukaan air laut dan membentuk kurva/grafik sinusoidal (Holthuijsen, 2007). Gelombang laut timbul akibat adanya gaya pembangkit yang bekerja pada laut. Gelombang yang terjadi di lautan dapat di klasifikasikan menjadi beberapa macam berdasarkan gaya pembangkitnya. Gaya pembangkit tersebut terutama berasal dari angin, gaya tarik menarik bumi - bulan - matahari atau yang di sebut dengan gelombang pasang surut dan gempa bumi (Nichols dan Williams 2009).

Gelombang merupakan faktor yang penting dalam pelayanan informasi meteorologi kelautan (marine meteorological services). Sering terjadinya gelombang tinggi tentu dapat menyebabkan terganggunya aktivitas nelayan, transportasi laut antar pulau yang dapat berdampak pada kehidupan masyarakat di darat, seperti kelangkaan bahan pangan di beberapa pulau kecil dan terganggunya berbagai aktifitas pembangunan karena terhambatnya suplai bahan-bahan konstruksi (Kurniawan et al., 2011).

Pada umumnya gelombang laut dibangkitkan oleh angin (sea wave) sehingga sifat-sifat gelombang tertentu dipengaruhi oleh angin, misalnya semakin kencang atau tinggi kecepatan angin maka kecepatan dan panjang gelombang semakin besar (Azis, 2006). Menurut BMKG, ada beberapa kriteria tingkat bahaya gelombang laut yaitu 1,25 - 2 meter berbahaya bagi perahu nelayan, 2 - 3 meter berbahaya bagi perahu nelayan dan tongkang, $3-4$ meter berbahaya bagi perahu nelayan, tongkang dan kapal feri, diatas 4 meter berbahaya bagi semua kapal.

\section{Angin Monsun}

Pengaruh Samudera Pasifik menjadi dominan pada periode angin baratan kecuali pada sebagian besar Sumatera, yang dipengaruhi oleh karakteristik Samudera Hindia sebelah barat. Sebaliknya pada musim angin timuran, pengaruh Samudera Hindia menjadi dominan dengan ditandai oleh berkurangnya curah hujan di Pulau Jawa, dan kepulauan Nusa Tenggara, sementara di sebagian besar Sumatera, dan Kalimantan masih berpeluang terjadinya curah hujan dengan intensitas sedang. Dinamika ini akan berpengaruh secara langsung terhadap dinamika yang terjadi di perairan Indonesia (Taryono, 2016).

Monsun adalah sistem sirkulasi regional yang mempunyai variasi musiman. Monsun ditandai oleh pembalikan musiman sistem angin utama, yang diartikan sebagai perubahan arah gaya gradient tekanan permukaan dan cuaca utama ketika musim panas (summer) dan ketika musim dingin (winter). Menurut Aldrian (2008), penyebab utama dari fenomena ini adalah pergerakan titik kulminasi matahari terhadap bumi yang bergerak utara selatan dan terciptanya kontras tekanan dan suhu antara benua dan samudera. Ditinjau dari kemantapan arah dan kecepatan angin monsun, maka di Indonesia dikenal dua musim yang meliputi bulan Desember, Januari, Februari dan Juni, Juli, Agustus 
(Bayong, 2008). Keadaan monsun di wilayah Indonesia dapat ditandai dengan berhembusnya secara tetap sirkulasi angin untuk satu periode tertentu (minimal 3 bulan) dan pada periode yang lain arah anginnya hampir berlawanan. Pada musim transisi antar kedua monsun yang terjadi pada Maret-April-Mei (MAM) dan September-Oktober-Nopember (SON), arah dan kecepatan angin bertiup tidak menentu (Nontji, 2005).

\section{METODE PENELITIAN}

\section{Waktu dan Tempat}

Penelitian ini menggunakan data kecepatan angin mulai dari Desember 2016 hingga November 2017 dengan lokasi penelitian berada di perairan
Kepulauan Mentawai dan sekitarnya. Peta Lokasi Penelitian terdapat pada Gambar 1.

\section{Data}

Metode yang digunakan dimulai dari pengumpulan data, pengolahan data dan analisis data hasil. Diagram alir penelitian disajikan pada Gambar 2 . Kegiatan pengumpulan data adalah berupa data arah dan kecepatan angin yang didapat dari BMKG Maritim Teluk Bayur.

Setting model pada Windwaves-12 adalah sebagai berikut:

- Periode tahun : Desember 2016 November 2017

(Data yang digunakan untuk melakukan running)

- Domain running model : 80W, 150E, $25 \mathrm{~N}, 25 \mathrm{~S}$

(Domain awal running forecasting)

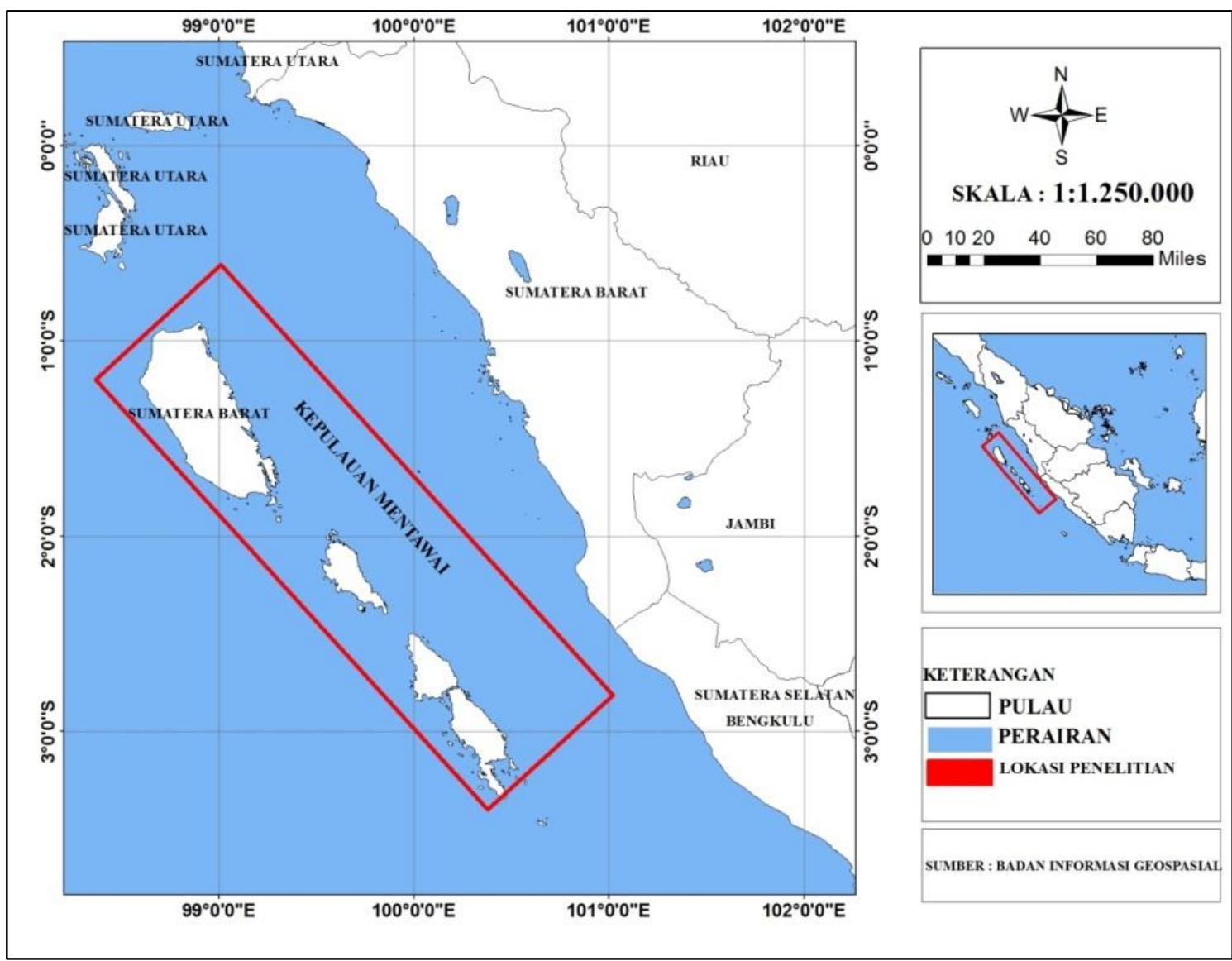

Gambar 1. Peta Lokasi Penelitian 
- Domain mapping : 94W, 104E, 1N, 7S (Domain layanan wilayah BMKG Teluk Bayur)

- Resolusi : 10 x 10 menit (Untuk prakiraan perairan sempit digunakan resolusi tinggi, sehingga makin kecil resolusi makin baik)

- Time step : 6 jam

(Untuk membuat analisis dan prakiraan dibuat dengan jarak interval 6 jam)

Untuk menganalisis karakteristik gelombang, ada beberapa tahap yang harus dilakukan seperti dibawah ini:

\section{a. Windwaves-12}

1. Buka Windwaves-12, Logon menggunakan nama user "admin".

2. Klik Forecast Setting untuk merubah konfigurasi model, kemudian pilih Edit untuk menyunting model yang akan digunakan dalam proses forecasting dan auto mapping. Selanjutnya klik Clarify untuk memastikan pengaturan model yang akan digunakan dan folder akan otomatis terbuat yang berada dipenyimpanan Local Disc. Lakukan setting pada bagian Model setting - Auto Mapping yaitu dengan mengatur lintang dan bujur sesuai dengan cakupan peta . Klik Clarify - save finish-Apply-quit.

3. Lakukan running data yang akan mengubah data format GRB menjadi file windwave, agar nantinya dalam proses monthly mapping dapat berlangsung. Monthly mapping berfungsi sebagai pemetaan data analisis bulanan. Sebelumnya data GRB dimasukan ke dalam file 0000.GFSA.GRIB. Lakukan Forecasting untuk membuat prakiraan kemudian tentukan tanggal sesuai dengan data yang akan digunakan, klik OK. Tunggu hingga selesai, kemudian Quit ( keluar).

4. Selanjutnya adalah klik monthly mapping yang berfungsi untuk membuat pemetaan analisis bulanan. Pilih bulan dan sesuaikan dengan tahun yang akan kita gunakan - OK, tunggu sebentar proses sedang berlangsung - Quit.

5. Data yang digunakan untuk membuat peta tersedia di file mapping-monthly .

\section{b. Membuat Layout Peta ArcVIEW 3.3}

1. Buka file yang tersedia dalam bentuk format APR (tlkbayurx_(res1440x900-32bit)_master).

File ini merupakan standar layout BMKG Teluk Bayur.

2. Setelah diklik, tampilan layout peta akan otomatis terbuka, lakukan klik pada windwaves tools yang berfungsi untuk memilih data yang dikehendaki dalam proses layout hasil dari pengolahan data pada Windwaves-12. Pilih monthly dikarenakan akan membuat layout bulanan, selanjutnya pilih average untuk rata-rata hasil keseluruhan data perbulan. Klik Frame-Yes + DEM theme - select all - pilih tlkbayur_monthly.txt - select all setting tahun data yang akan digunakan dalam layout peta. Kemudian pilih select all - Yes sesuaikan data bulanan yang akan digunakan, klik spline - OK - select all- $\mathrm{OK}$ - select all dan OK. 
3. Layout peta bulanan yang telah selesai akan tersimpan di dalam folder image STA_TLKBAYUR.
4. Setelah proses layout peta selesai, lakukan analisis karakteristik gelombang.

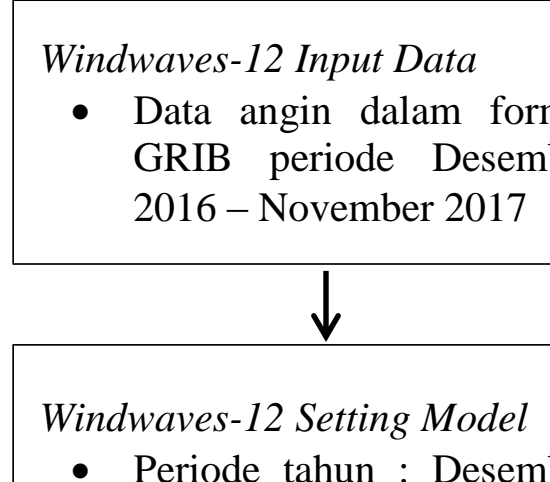

- Periode tahun : Desember 2016 - November 2017

- Domain running model : $80 \mathrm{~W}, 150 \mathrm{E}, 25 \mathrm{~N}, 25 \mathrm{~S}$

- Domain mapping : $94 \mathrm{~W}$, 104E, 1N, 7S

- Resolusi : 10 x 10 menit

- Time step : 6 jam

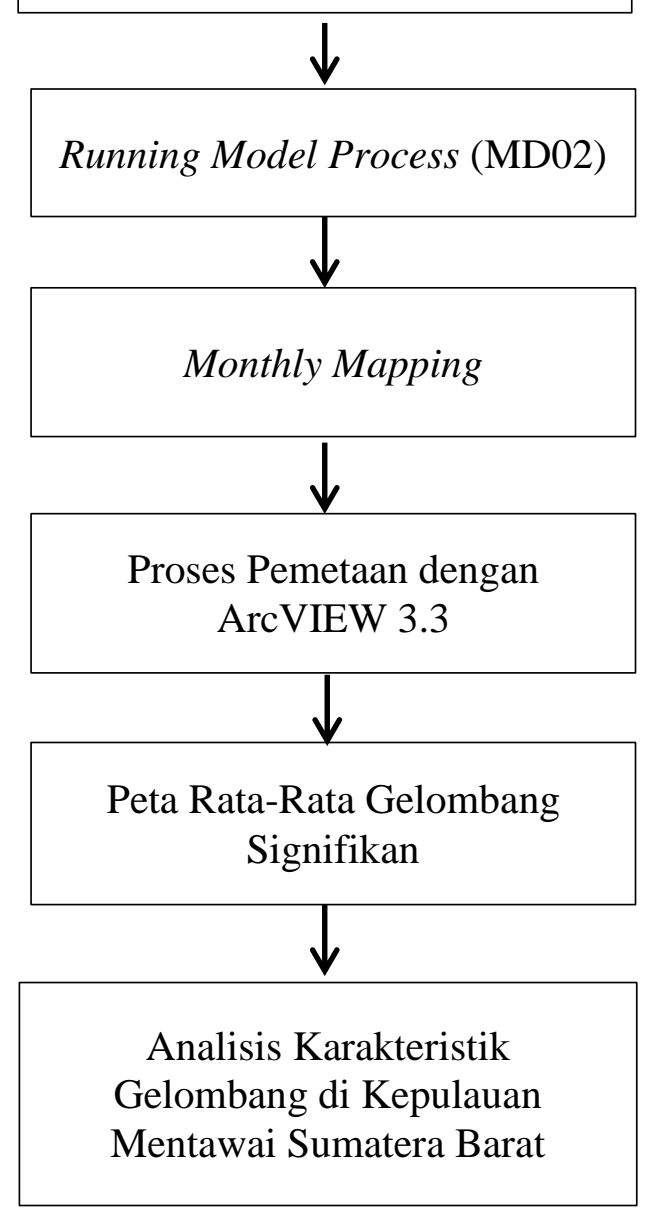

Gambar 2. Diagram Alir Penelitian 


\section{GELOMBANG SIGNIFIKAN \\ PERAIRAN KEPULAUAN \\ MENTAWAI BERDASARKAN MUSIM ANGIN}

\section{Desember 2016 - Februari 2017 \\ (Musim Barat)}

Karakteristik gelombang signifikan pada bulan Desember 2016 (Gambar 3) yaitu memiliki ketinggian $0,50-2,0 \mathrm{~m}$ dari arah barat - timur, kecepatan angin 5-15 knot dan termasuk ke dalam kategori gelombang sedang. Pada Gambar 4, di bulan Januari 2017 ketinggian gelombang signifikan mencapai $0,50-2,0 \mathrm{~m}$, memiliki arah barat - tenggara, kecepatan angin 5 10 knot dan termasuk ke dalam kategori gelombang sedang. Sedangkan pada bulan Februari 2017 (Gambar 5), ketinggian gelombang signifikan mencapai 0,50-1,25 $m$ dengan arah barat - timur, kecepatan angin 5 - 10 knot dan termasuk kategori gelombang rendah.

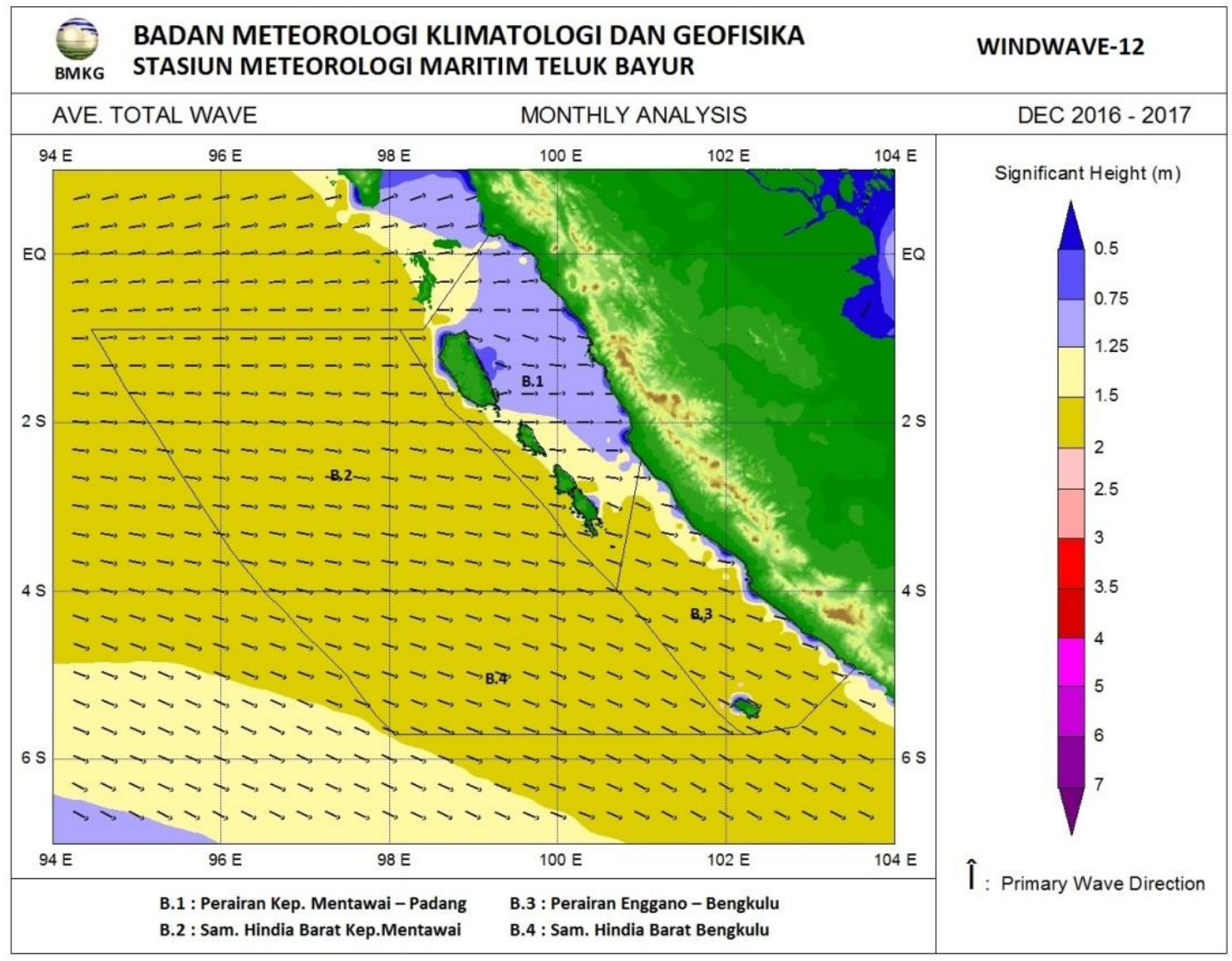

Gambar 3. Gelombang signifikan bulan Desember 2016 - Januari 2017 


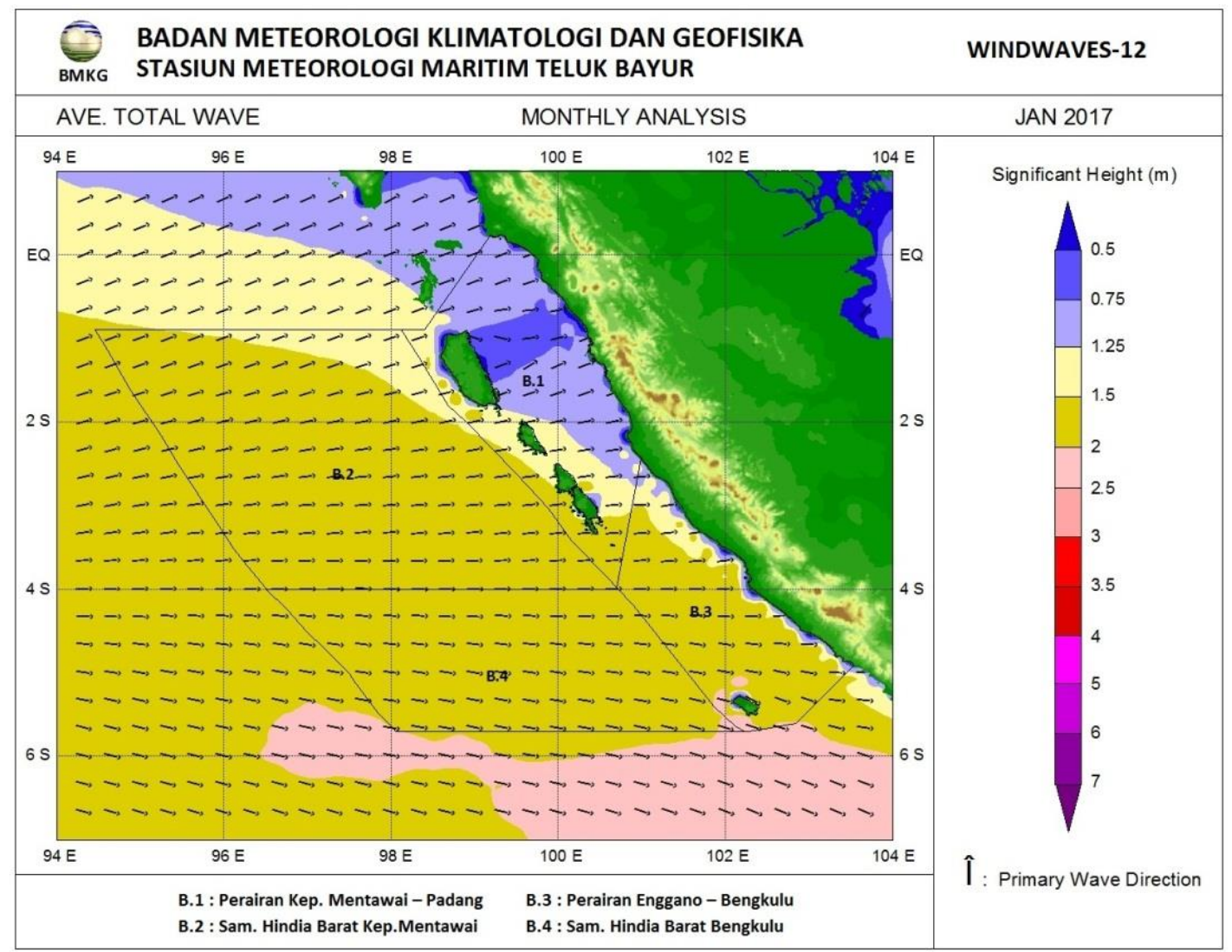

Gambar 4. Gelombang signifikan bulan Januari 2017

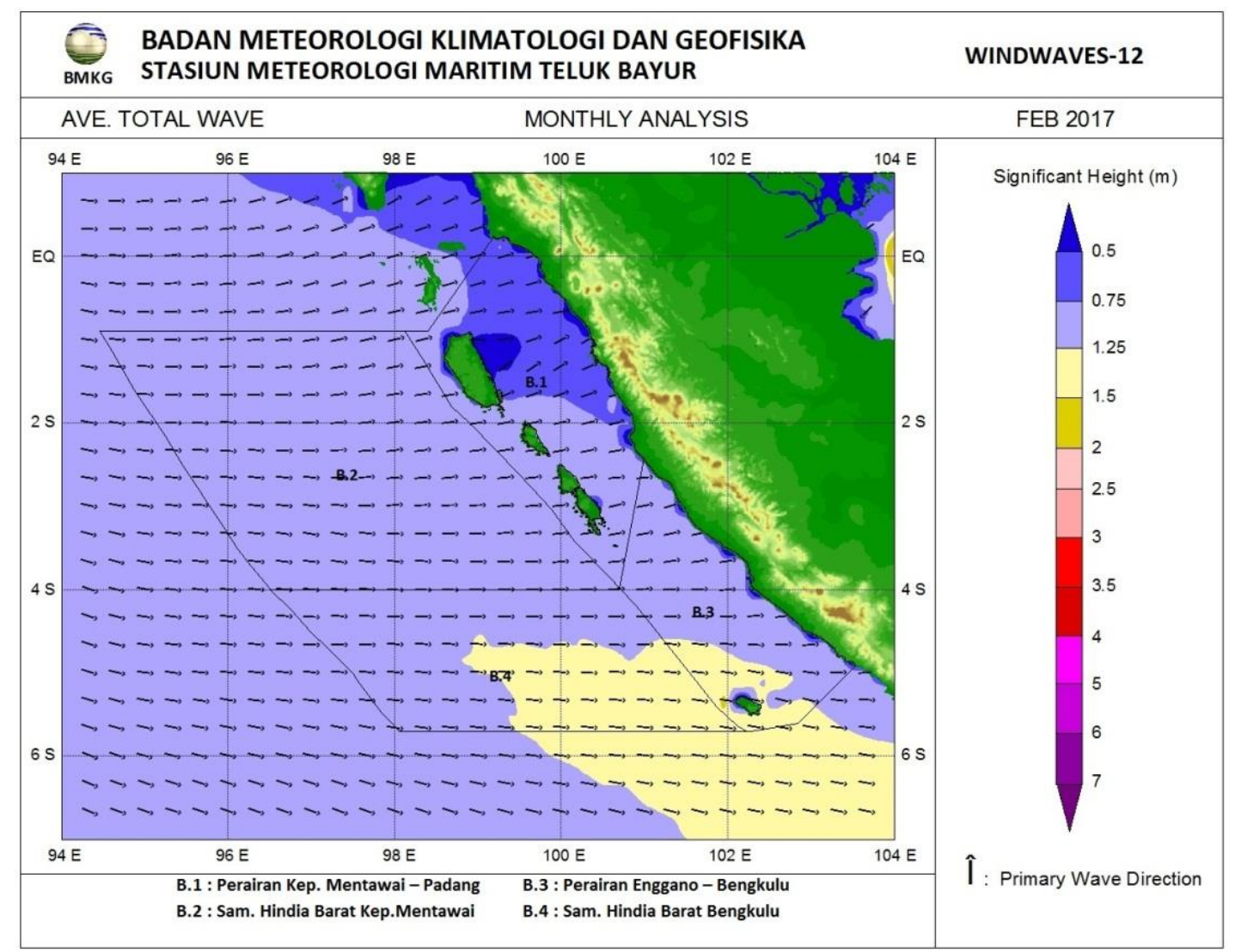

Gambar 5. Gelombang signifikan bulan Februari 2017 


\section{Maret - Mei 2017 (Musim Peralihan I)}

Karakteristik gelombang pada musim peralihan I bulan Maret 2017 (Gambar 6) yaitu memiliki ketinggian gelombang signifikan 0,50-1,25 m dengan arah barat - timur sehingga masih termasuk ke dalam kategori gelombang rendah dan kecepatan angin 5 - 10 knot.

Pada Gambar 7, dapat dilihat bahwa karakteristik gelombang signifikan pada bulan April memiliki ketinggian gelombang signifikan $0,50-1,25 \mathrm{~m}$ dengan kategori gelombang rendah, arah gelombang dari barat - timur laut dan kecepatan angin 5 knot. Gelombang signifikan pada bulan Mei (Gambar 8) yaitu 0,50 - 1,25 m termasuk dalam kategori gelombang rendah dengan arah tenggara barat laut dan kecepatan angin 5 knot.

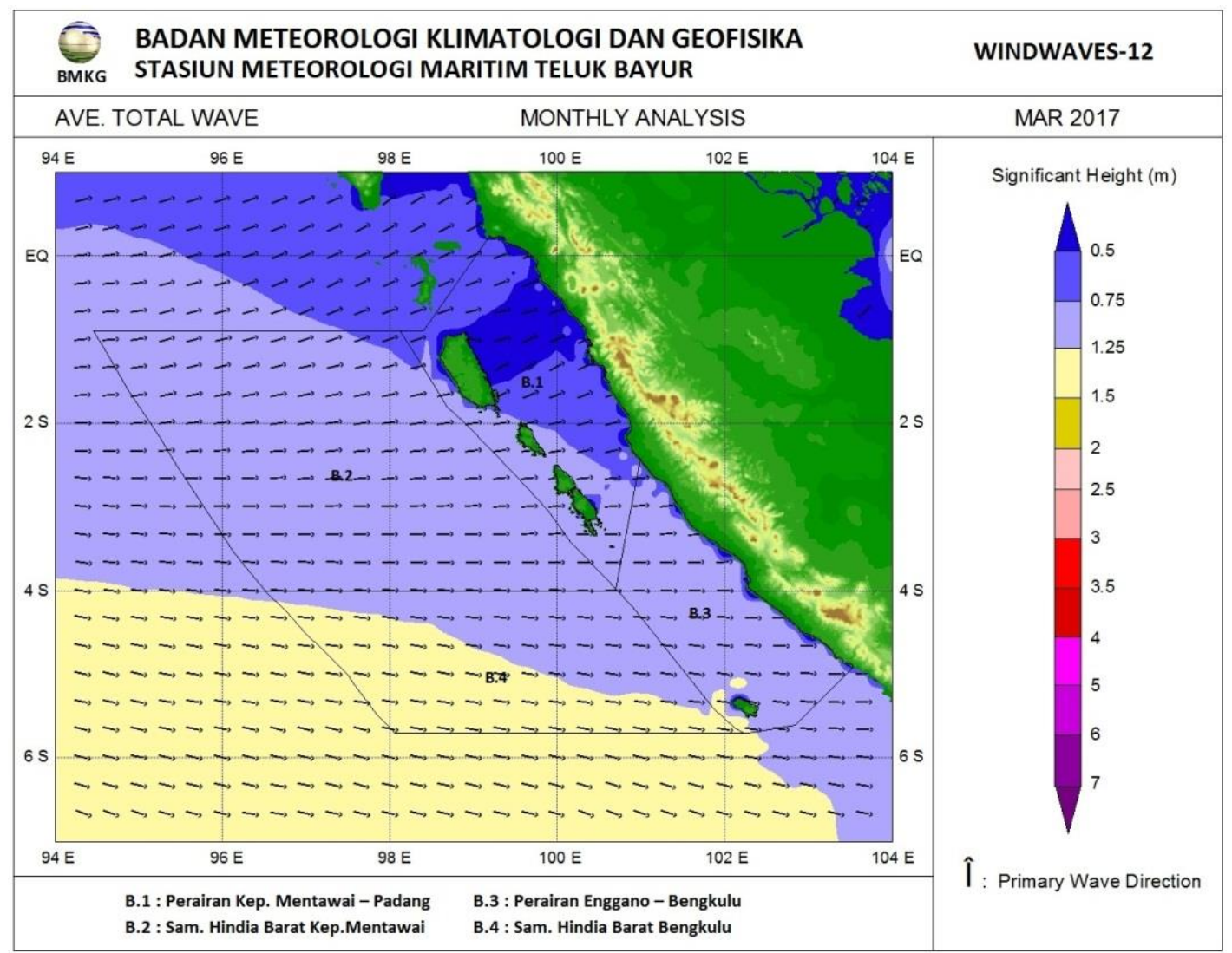

Gambar 6. Gelombang signifikan bulan Maret 2017 


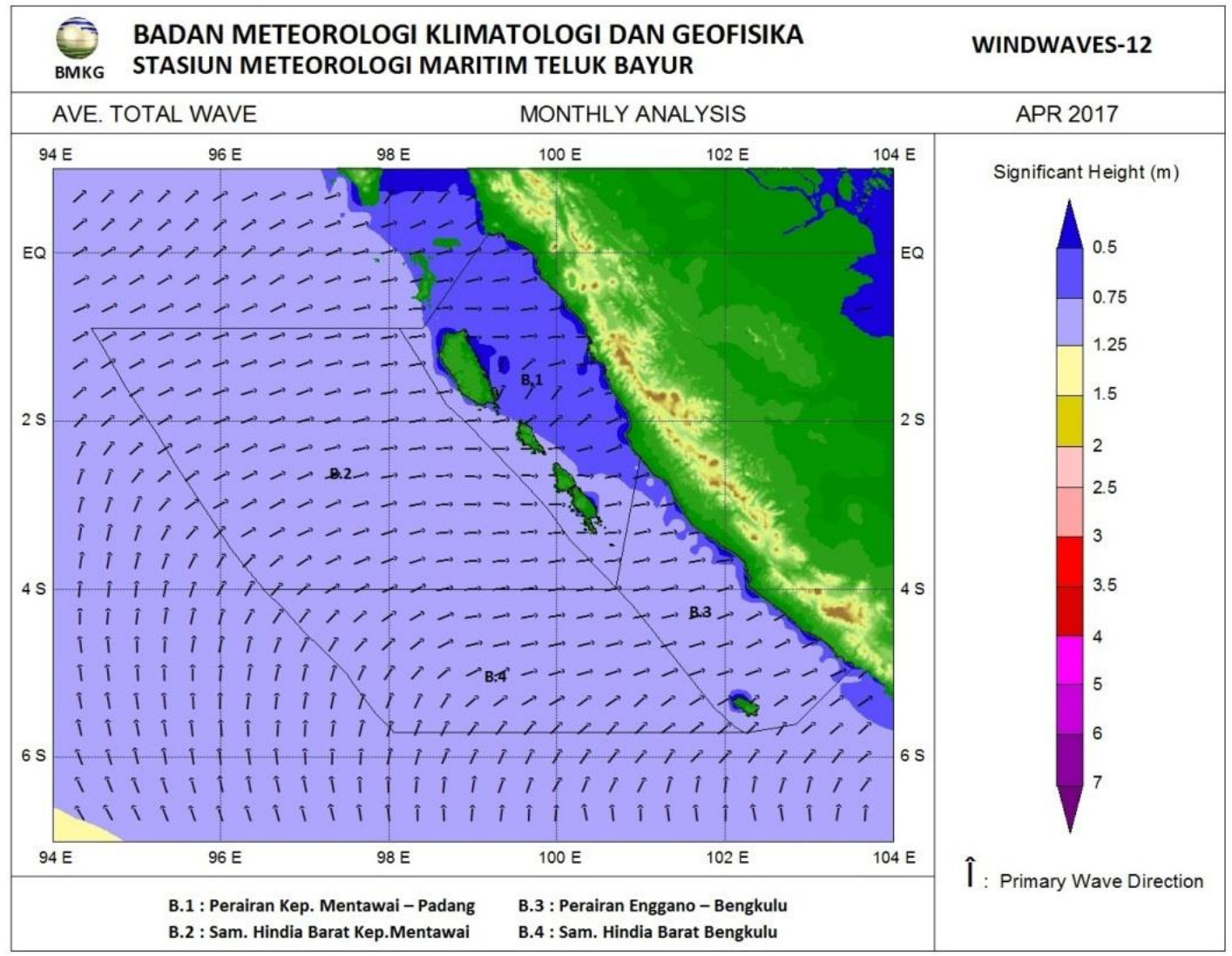

Gambar 7. Gelombang signifikan bulan April 2017

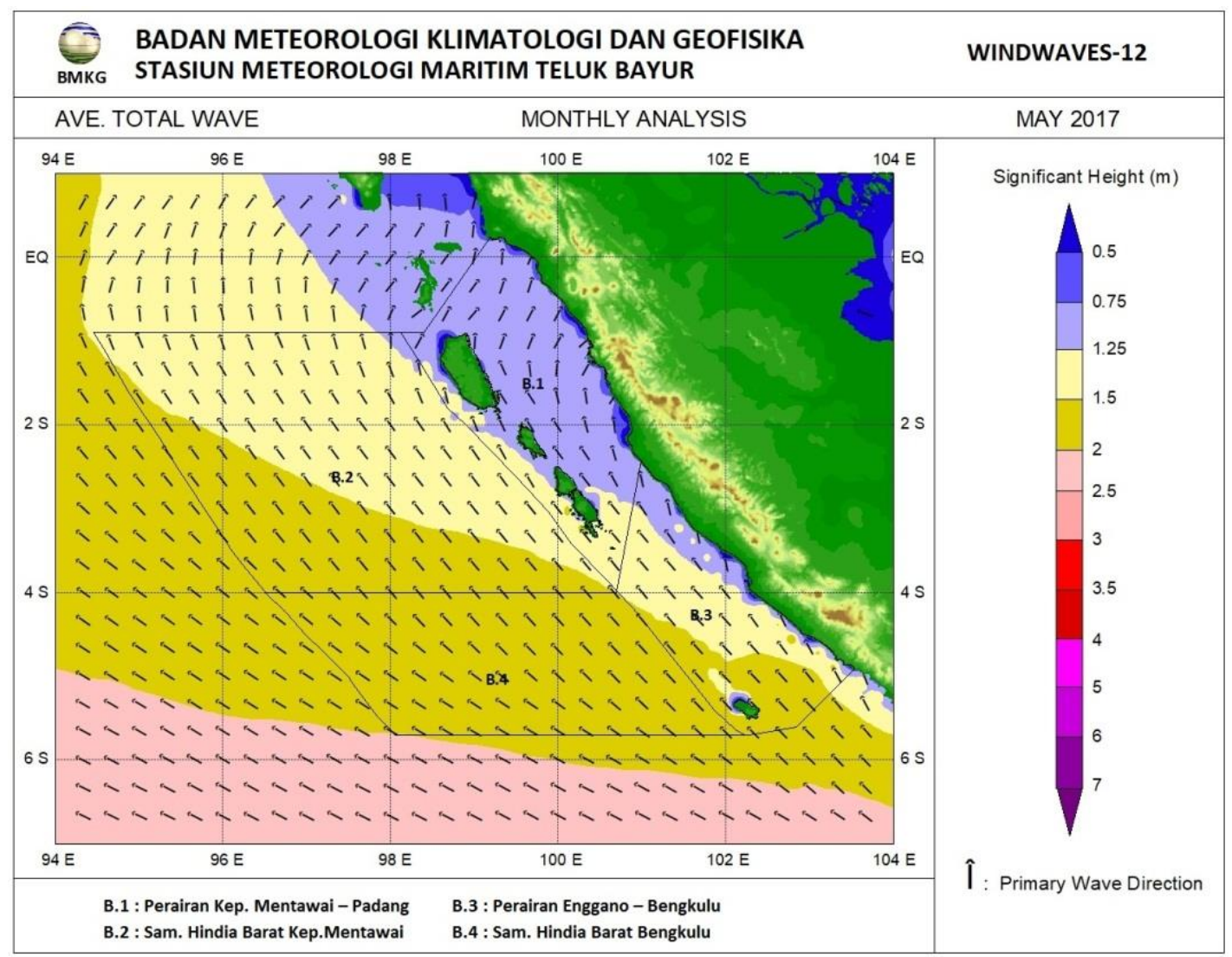

Gambar 8. Gelombang signifikan bulan Mei 2017 


\section{Juni - Agustus 2017 (Musim Timur)}

Bulan Juni 2017 (Gambar 9) memiliki tinggi gelombang signifikan yaitu 0,50 - 1,25 m termasuk ke dalam kategori gelombang rendah dengan arah timur barat laut dan kecepatan angin 5 knot. Karakteristik gelombang pada bulan Juli (Gambar 10) memiliki tinggi gelombang 0,50 - 2,0 m termasuk ke dalam kategori gelombang sedang dengan arah tenggara barat laut dan kecepatan angin 5 - 10 knot. Pada Gambar 11, dapat dilihat bahwa karakteristik gelombang bulan Agustus memiliki ketinggian gelombang signifikan 0,50 - 2,0 m termasuk kategori gelombang sedang dengan arah tenggara - barat laut dan kecepatan angin 5-15 knot.

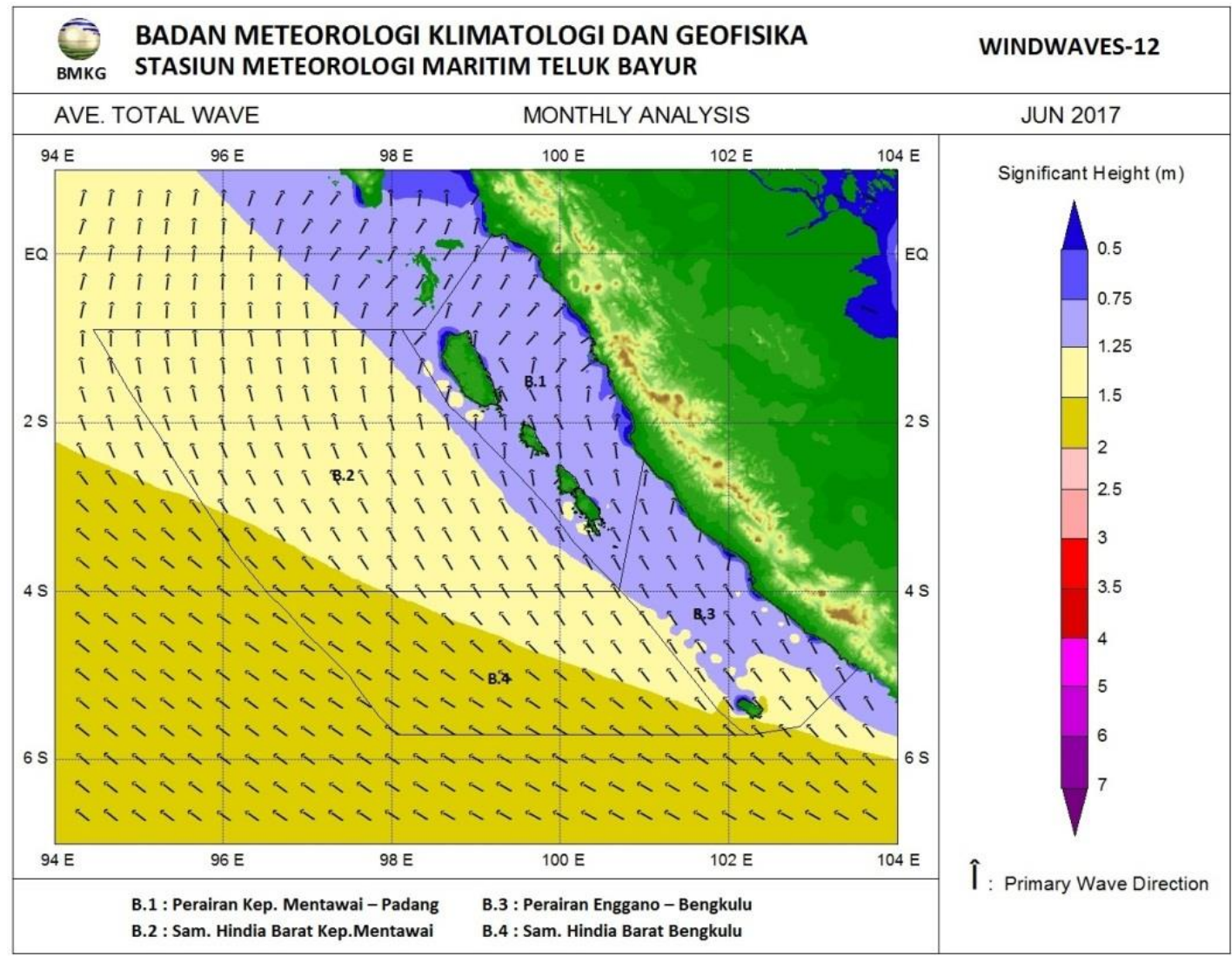

Gambar 9. Gelombang signifikan bulan Juni 2017 


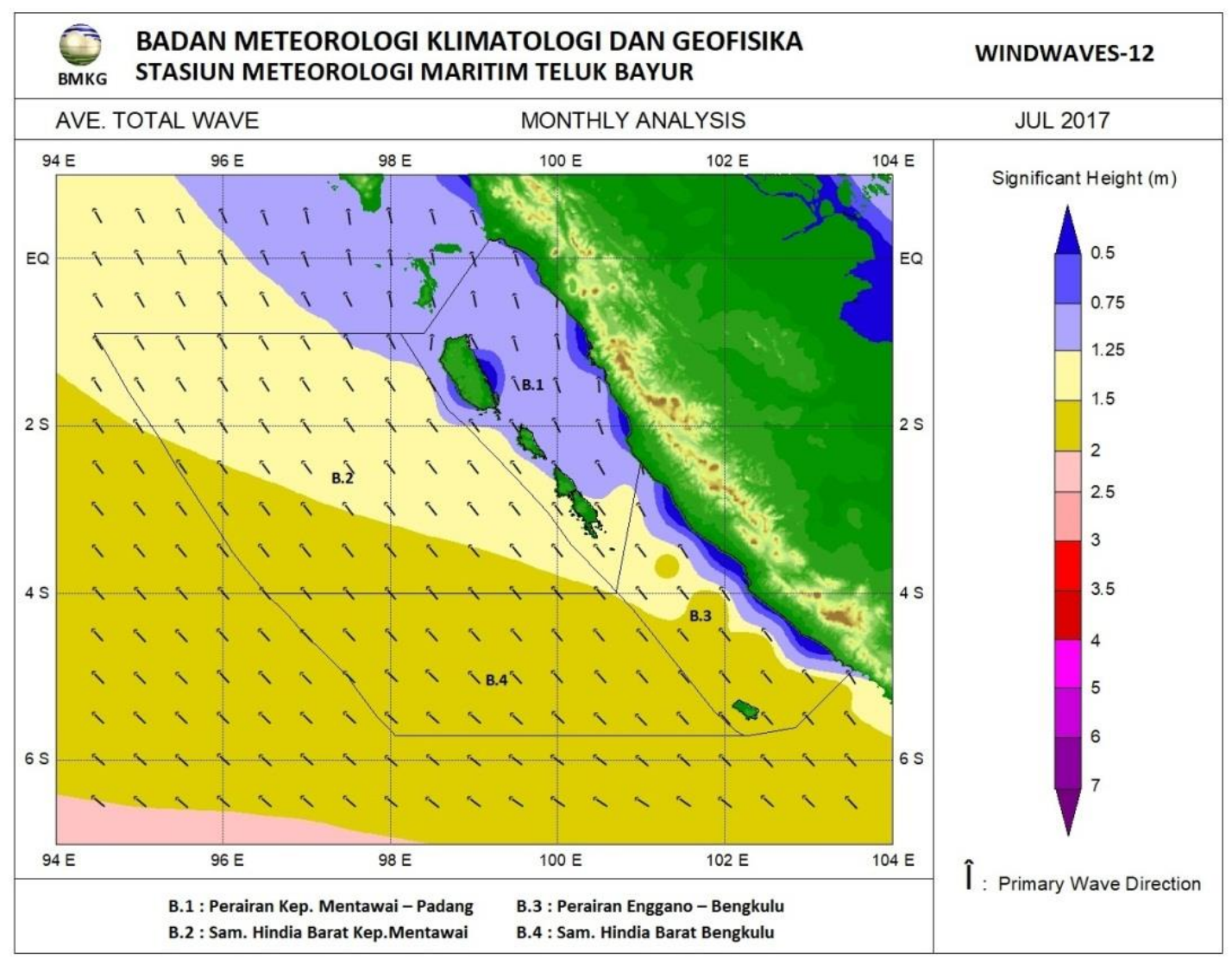

Gambar 10. Gelombang signifikan bulan Juli 2017

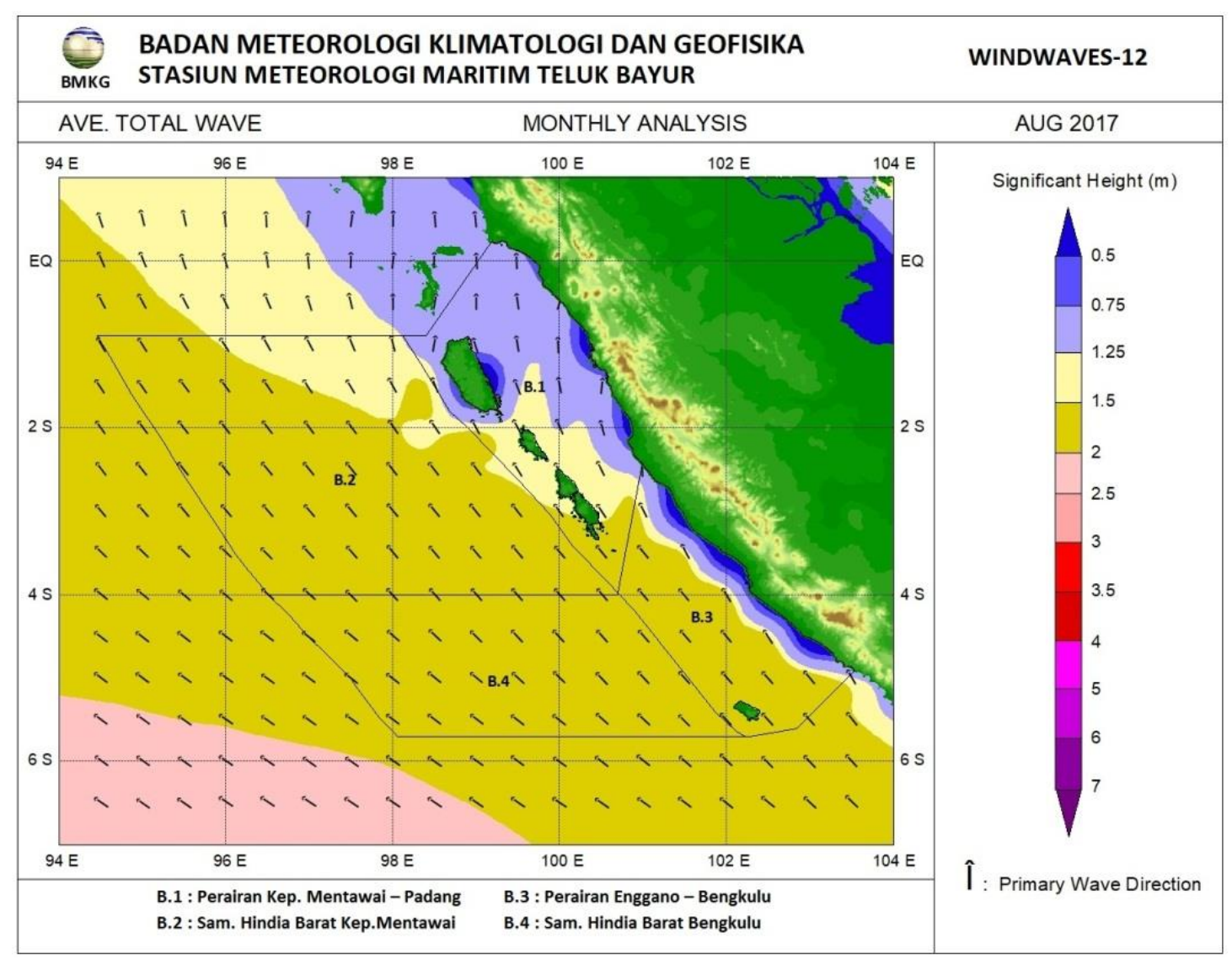

Gambar 11. Gelombang signifikan bulan Agustus 2017 


\section{September - November 2017 (Musim Peralihan II)}

Pada musim peralihan II, di bulan September 2017 (Gambar 12) ketinggian gelombang signifikan mencapai $0,50-2,0$ $\mathrm{m}$ yang masuk ke dalam kategori gelombang sedang dengan arah tenggara barat laut dan kecepatan angin 5 - 10 knot. Pada bulan Oktober (Gambar 13), karakteristik gelombang signifikan mencapai $0,50-1,50 \mathrm{~m}$ yang termasuk ke dalam kategori gelombang sedang dengan arah tenggara - barat laut dan kecepatan angin 5 knot. Gelombang signifikan pada bulan November (Gambar 14) mencapai ketinggian 0,50 - 1,50 m dengan kategori gelombang rendah mengarah ke barat laut tenggara dan kecepatan angin 5 - 10 knot.

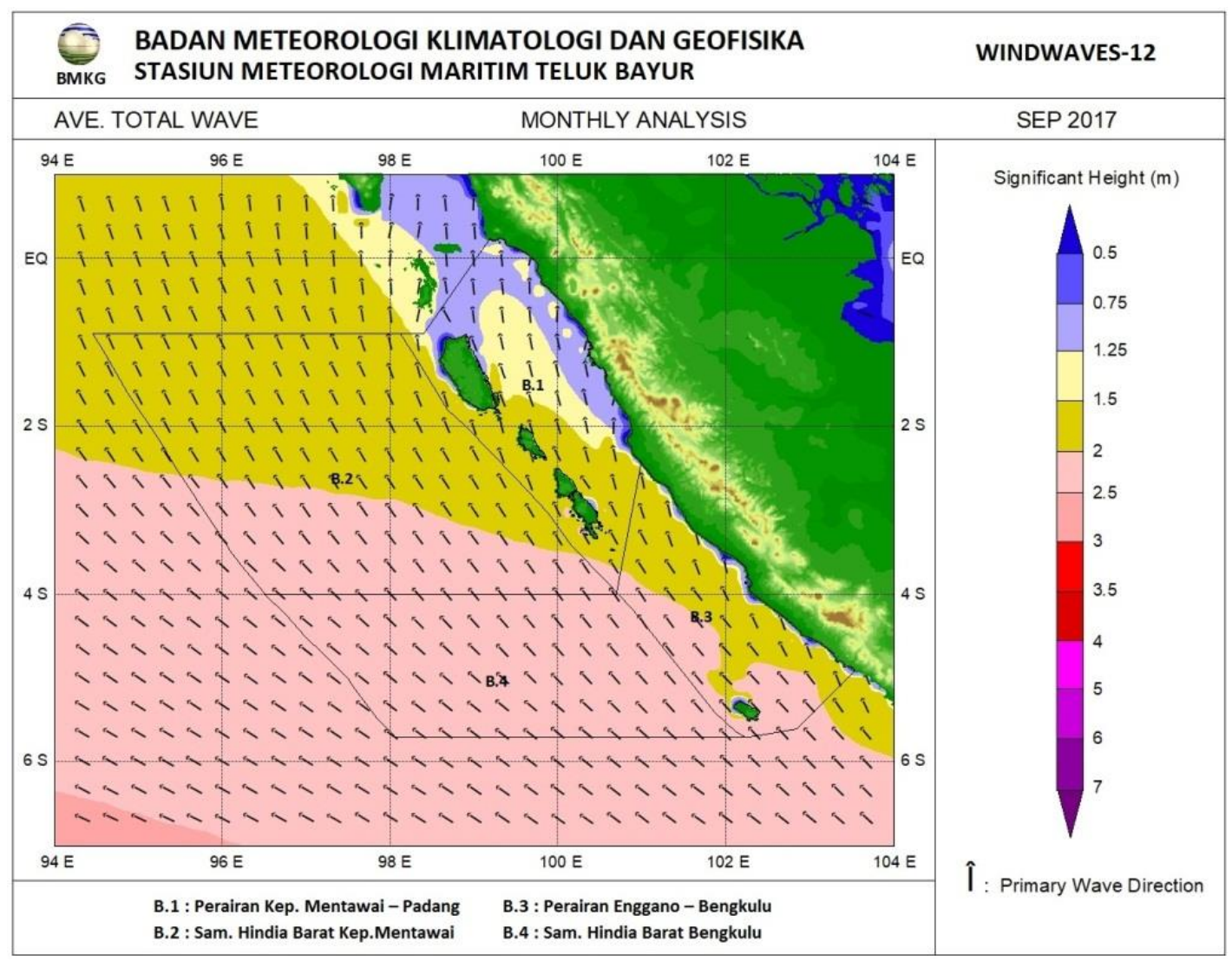

Gambar 12. Gelombang signifikan bulan September 2017 


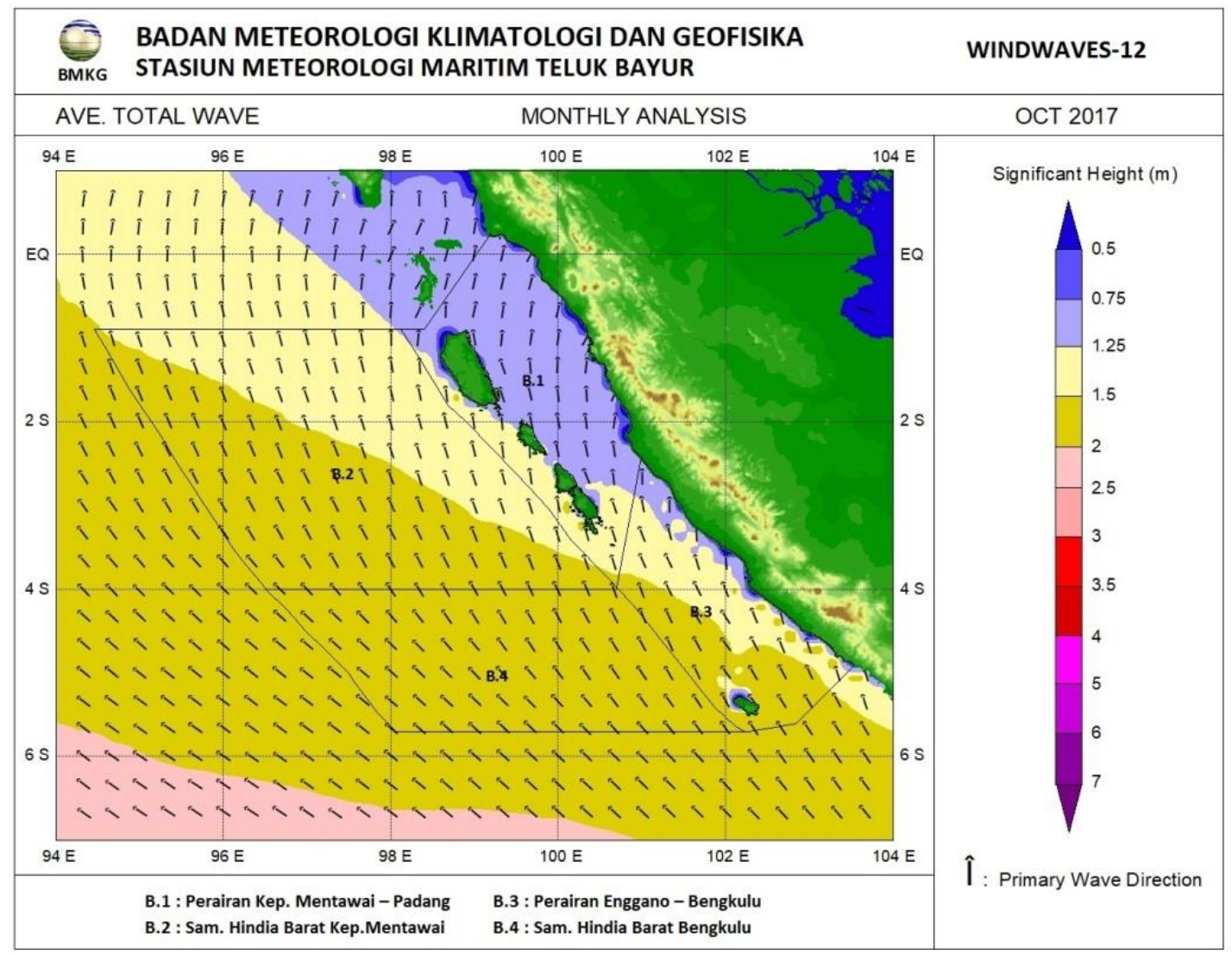

Gambar 13. Gelombang signifikan bulan Oktober 2017

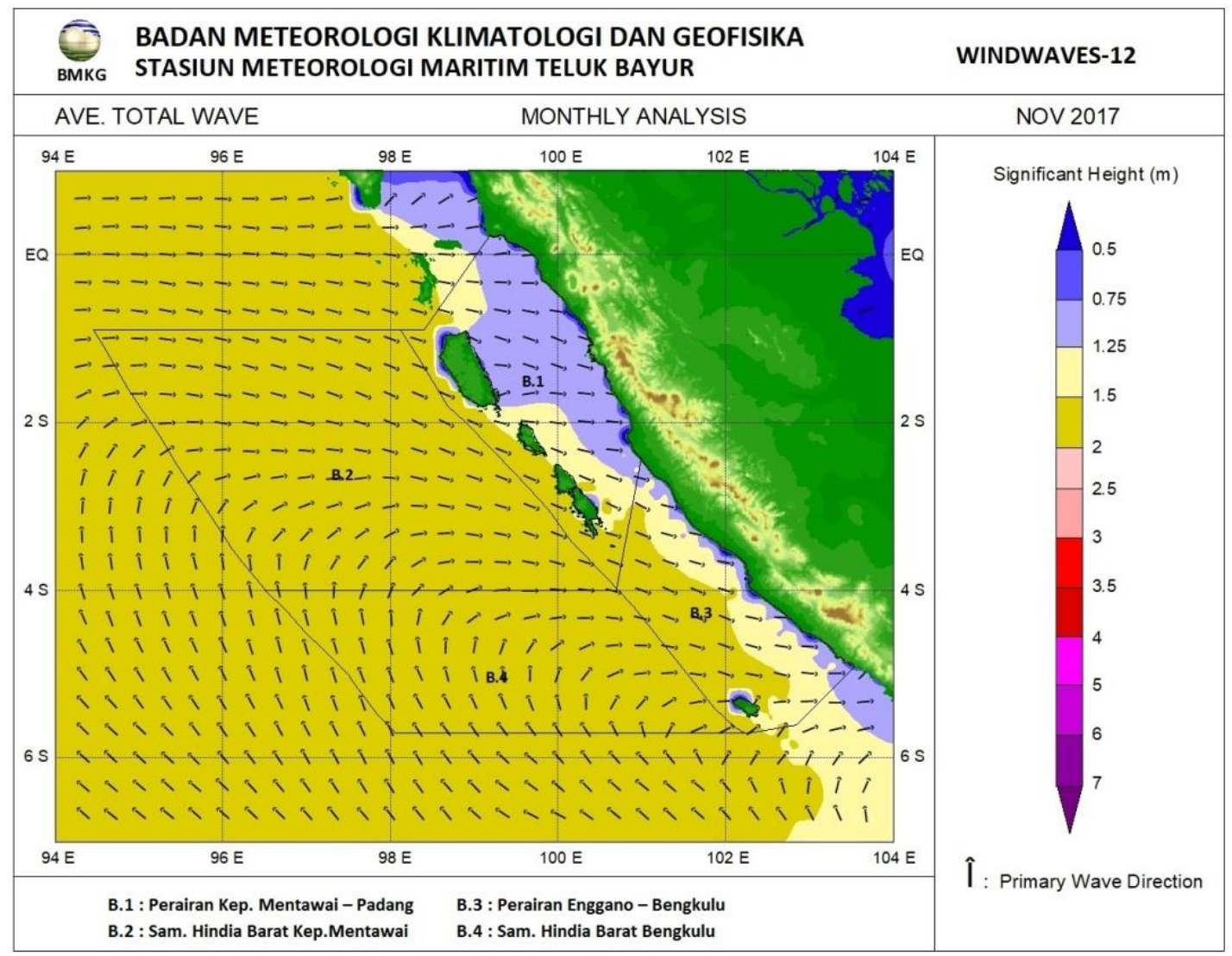

Gambar 14. Gelombang signifikan bulan November 2017 


\section{PEMBAHASAN}

Kondisi gelombang signifikan pada musim barat (Desember - Februari) memiliki rata-rata ketinggian gelombang $0,50-2,0 \mathrm{~m}$. Pada musim barat, angin bertiup dari timur laut dan berbelok menuju arah tenggara. Namun berdasarkan analisis data yang terjadi, angin bertiup dari arah barat laut dan berbelok ke arah tenggara serta arah gelombang dari barat menuju timur. Hal ini dapat disebabkan karena perairan Kepulauan Mentawai merupakan perairan tertutup sehingga kekuatan arus dan gelombang akan berkurang.

Hal ini sesuai dengan penelitian yang dilakukan oleh Kurniawan et al. (2011). Rata-rata tinggi gelombang di bulan Desember pada wilayah-wilayah yang berbatasan dengan laut lepas, yaitu baik Samudera Hindia, Samudera Pasifik maupun Laut Cina Selatan, mempunyai rata-rata tinggi gelombang yang relatif lebih tinggi dibanding dengan daerah lain. Wilayah ini meliputi perairan sebelah barat Sumatera sampai perairan sebelah selatan Jawa, Selat Karimata, Laut Sulawesi bagian utara, dan Laut Maluku. Sama halnya dengan perairan sekitar Papua yang berbatasan dengan Samudera Pasifik bagian barat, dimana pada daerah tersebut tinggi gelombang signifikan mencapai 1,50 $-2,0$ meter.

Rata-rata gelombang signifikan pada musim peralihan I (Maret - Mei) mencapai ketinggian $0,50-1,25$ dan termasuk ke dalam kategori gelombang rendah dengan kecepatan angin 5-10 knot. Pada musim ini, kecepatan angin termasuk rendah dikarenakan posisi matahari berada di garis khatulistiwa. Aktivitas nelayan serta kapal penyebrangan pada musim ini masuk dalam kategori aman.
Menurut penelitian yang dilakukan oleh Kurniawan et al. (2013), pada bulan Maret - Mei nilai gelombang signifikan di Samudera Hindia sepanjang Sumatra dan Jawa menunjukkan hasil yang rendah dibandingkan dengan musim barat.

Musim timur (Juni - Agustus) memiliki karakteristik gelombang rata-rata yaitu 0,5-2,0 m dengan kecepatan angin 5 - 15 knot. Karakteristik gelombang ini berbahaya bagi aktivitas nelayan. Pada musim ini, angin bertiup dari tenggara dan berbelok ke arah timur laut setelah melalui garis khatulistiwa. Akan tetapi, hasil analisis data menunjukkan angin bertiup dari tenggara menuju barat laut yang dapat disebabkan oleh karakteristik perairannya yakni tipe perairan tertutup. Berdasarkan penelitian yang telah dilakukan oleh Supiyati (2008), pada musim timur gelombang dominan terjadi dengan ketinggian 1,0-3,0 m.

Musim peralihan II (September November) memiliki karakteristik gelombang dengan ketinggian 0,50 - 2,0 m dengan kecepatan angin 5-10 knot. Memasuki musim ini, matahari berada di posisi garis khatulistiwa sehingga nilai tekanan berbeda dengan musim barat dan timur. Kewaspadaan para nelayan harus ditingkatkan jika ingin melaut di musim ini, namun bagi kapal tongkang maupun feri musim ini masih tergolong aman. Pada penelitian di musim peralihan II yang telah dilakukan oleh Kurniawan et al. (2011), tinggi gelombang disebutkan mencapai $1,25-2,5 \mathrm{~m}$.

\section{KESIMPULAN}

Perairan laut di Kepulauan Mentawai merupakan perairan laut yang berhadapan langsung dengan Samudera Hindia bagian barat. Tinggi rendahnya gelombang laut 
dapat dipengaruhi oleh kecepatan angin yang berhembus serta pergantian musim dimana matahari berada pada posisi khatulistiwa, sehingga menyebabkan perbedaan pada tekanan udara. Gelombang signifikan tertinggi terjadi pada saat musim barat dan musim timur.

Wisata selancar yang diminati oleh wisatawan asing maupun lokal dapat dinikmati pada musim barat dan timur, namun bagi aktivitas kapal penyebrangan harus berwaspada di musim ini. Potensi gelombang yang signifikan di perairan Kepulauan Mentawai dapat dimanfaatkan seperti untuk pemanfaatan energi gelombang laut. Diperlukan penelitian lebih lanjut untuk mendapatkan nilai dan sebaran potensi energi gelombang laut, dan hasil dari penelitian ini dapat digunakan sebagai referensi.

\section{DAFTAR PUSTAKA}

Aldrian, E. 2008. Meteorologi laut Indonesia. Jakarta: Badan Meteorologi Klimatologi dan Geofisika (BMKG).

Azis, MF. 2006. Gerak air di laut. Oseana 31(4): 9-21.

Badan Meteorologi Klimatologi dan Geofisika (BMKG). Meteorologi Laut Indonesia. Jakarta.

Bayong, Tj.H.K. 2008. Sains atmosfer. Jakarta: Badan Meteorologi Klimatologi dan Geofisika.

Dewi, Amalia., Purwanto., Sugianto, D. Nugroho. 2017. Analisis deformasi gelombang di Pulau Siberut Kabupaten Kepulauan Mentawai

Sumatera Barat. Jurnal
Oseanografi. 6(2): 330-340.

Holthuijen, L. H 2007.Waves in Oceanic and Coastal Waters. New York, Cambride University Press.

Kurniawan, Roni., Habibie, M. Najib., Suratno. 2011. Variasi bulanan gelombang laut di Indonesia. Jurnal Meteorologi dan Geofisika. 12(3): 221-232.

Kurniawan, Roni., Permana, S.Donaldi., Suratno., M. Najib. 2013. Verifikasi Luaran Model Gelombang Windwaves-05 dengan Satelit Altimeter. Jurnal Meteorologi dan Geofisika 14(3): 149-158.

Nichols, C.R., \& Williams R.G. 2009. Encyclopedia of Marine Science. New York

Nontji, A. 2005. Laut nusantara. 4th ed. Jakarta: Jambatan.

Supiyati. 2008. Analisis Peramalan Gelombang Laut Dengan Periode Ulang Menggunakan Metode Gumbel Fisher Tippet-Tipe1 Studi Kasus: Perairan Pulau Baai Bengkulu. Gradien 4(2): 349-353.

Taryono., Sofian, Ibnu., Tisiana, A. Rita., Mustika, A. Tasdik. 2016. Analisis panjang dan tinggi gelombang untuk operasi KRI TNI- AL di Perairan Indonesia. Jurnal Chart Datum. 1(2): 72-87.

UU RI No. 27 Tahun 2007 Tentang

Pengelolaan Wilayah Pesisir dan Pulau-Pulau Kecil.

UU RI No. 49 Tahun 1999 Tentang

Pembentukan Kabupaten

Kepulauan Mentawai. 